\title{
PENGUATAN MANAJEMEN PENDIDIKAN DALAM MUTU PENDIDIKAN TINGGI STUDI KASUS DI STIE IBMT SURABAYA
}

\author{
Rachman Halim Yustiyawan \\ Progam Studi Manajemen STIE IBMT Surabaya \\ Email: rachman@ibmt.ac.id
}

\begin{abstract}
Abstrak : Pendidikan dianggap sebuah investasi yang berharga dalam membentuk sumber daya manusia dalam meningkatkan peradaban bangsa dan negara. Manajemen pendidikan menjadi alat utama untuk memberikan relevansi antara tujuan perguruan tinggi, tujuan pendidikan tinggi dan tujuan pendidikan nasional. Pendidikan tinggi merupakan lembaga formal jenjang terakhir yang memberikan kontribusi peningkatan kompetensi sumber daya manusia sehingga memiliki kualifikasi dan keahlian tertentu. Peningkatan mutu perguruan tinggi harus disesuaikan dengan standar pendidikan tinggi. Relevansi ini dilakukan dengan harapan kepada perguruan tinggi dalam aktivitas menyelenggarakan pendidikan dengan menganalisa faktor apa saja yang dapat mendorong tercapainya standar pendidikan tinggi. Standarisasi pendidikan tinggi adalah batasan minimal yang harus dipenuhi, dan peningkatan mutu perguruan tinggi ini harus dilakukan menyesuaikan tuntutan perubahan dan perkembangan yang selalu meningkat. Penelitian ini suatu usaha yang terencana dan terstruktur dalam meningkatkan mutu perguruan tinggi. Penelitian ini dilakukan menggunakan metode pendekatan kualitatif dengan tujuan untuk menganalisa penguatan menejemen pendidikan di perguruan tinggi, dan mengidentifikasi masalah mutu perguruan tinggi, serta mengukur kekuatan kelemahan, peluang dan ancaman perguruan tinggi dalam menyelenggarakan pendidikan tinggi. Hasil penelitian ini menunjukan penguatan manajemen pendidikan merupakan aspek tentang bagaimana mengelola dan memberdayakan sumber daya untuk mencapai tujuan pendidikan yang telah ditetapkan secara produktif dan kondusif, kian memiliki peranan yang penting dalam menentukan mutu perguruan tinggi yang akan berdampak kepada tercapainya tujuan pendidikan nasional. Relevansi tersebut direalisasikan melalui tiga hal dasar yang harus dipenuhi oleh organisasi pendidikan yakni materi, energi, dan informasi.
\end{abstract}

Kata Kunci: Manajemen Pendidikan, Mutu, Pendidikan Tinggi

\begin{abstract}
Education is considered a valuable investment in shaping human resources in enhancing national and state civilizations. Education management becomes the primary tool to provide relevance between college objectives, higher education objectives and national educational objectives. Higher education is a last-level formal institution that contributes to the improvement of human resources ' competence, thus having certain qualifications and expertise. College quality improvement should be adjusted to higher education standards. This relevance is done in hopes to the college in conducting educational activities by analyzing any factors that can encourage the achievement of higher education standards. The standardization of higher education is the minimum limitation that must be met, and the quality improvement of this university should be done adjusting the demands of change and growth is always increasing. This research is a planned and structured business in improving the quality of the college. This research is conducted using a qualitative approach method with the aim of analyzing the strengthening of education management in universities, and identifying the quality problems of universities, as well as measuring the strengths of weaknesses, opportunities and In organizing higher education. The results of this research show that strengthening education management is an aspect of how to manage and empower resources to achieve the objectives of education that has been established productively and conducive, increasingly has the role Determining the quality of the colleges that will impact the achievement of national education objectives. The relevance is realized through three basic things that education organizations have to fulfill, i.e. material, energy, and information.
\end{abstract}

Keyword: educational management, quality, higher education. 
Pendidikan adalah jalan menuju kesejahteraan suatu bangsa. Pendidikan menjadi faktor utama dalam mencetak sumberdaya manusia yang unggul demi mencapai kehidupan yang lebih baik (Nuraeni, 2010). Peranan pendidikan tidak hanya kepada individu melainkan akan berujung kepada kualitas hidup masyarakat yang lebih baik. Undang Undang no 20 Tahun 2003 Tentang Sistem Pendidikan Nasional, menjelaskan bahwa pendidikan adalah usaha sadar dan terencana untuk mewjudkan suasana belajar dan proses pembelajaran agar peserta didik secara aktif mengembangkan potensi dirinya untuk memiliki kekuatan spiritual keagamaan, pengendalian diri, kepribadian, kecerdasan, ahlak mulia, serta keterampilan yang diperlukan dirinya dalam bermasyarakat, bangsa dan negara. Sistem pendidikan harus mampu menjamin pemerataan kesempatan pendidikan, peningkatan mutu serta relevansi dan efisiensi manajemen pendidikan untuk menghadapi tantangan sesuai dengan tuntutan perubahan kehidupan lokal, nasional, global, sehingga diperlukan pembaharuan pendidikan secara terencana, terarah, dan berkesinambungan (Anwar, 2014).

Sistem Pendidikan Nasional menunjukkan diperlukannya manajemen pendidikan secara nasional yang tertata, terarah, terstruktur, dalam satu kesatuan (Basri \& Rusdiana, 2015). Pendidikan tinggi sebagai jenjang tertinggi, berperan penting dalam mewujudkan tujuan dan sistem pendidikan nasional. Posisi perguruan tinggi sistem pendidikan nasional dilihat pada gambar 1 .

Sistem pendidikan nasional dilakukan dengan harapan dapat terwujudnya tujuan pendidikan nasional sebagai akumulasi dari peran dan fungsi pendidikan tinggi dan perguruan tinggi sebagai penyelenggara penddikan yang dirumuskan melalui visi dan misi perguruan tinggi.

Sistem pendidikan nasional memberikan prosi pendidikan tinggi dalam peran dan fungsi (Suharsaputra, 2015) untuk :

- Mengembangkan dan menumbuhkan kemampuan, membentuk watak, serta peradaban bangsa yang bermartabat dalam rangka mencerdaskan kehidupan bangsa,

- Mengembangkan sivitas akademika yang inovatif, responsif, kreatif, terampil, berdaya saing, dan kooperatif melalui tri dharma perguruan tinggi,

- Mengembangkan ilmu pengetahuan dan teknologi dengan memperhatikan dan menerapkan nilai humaniora

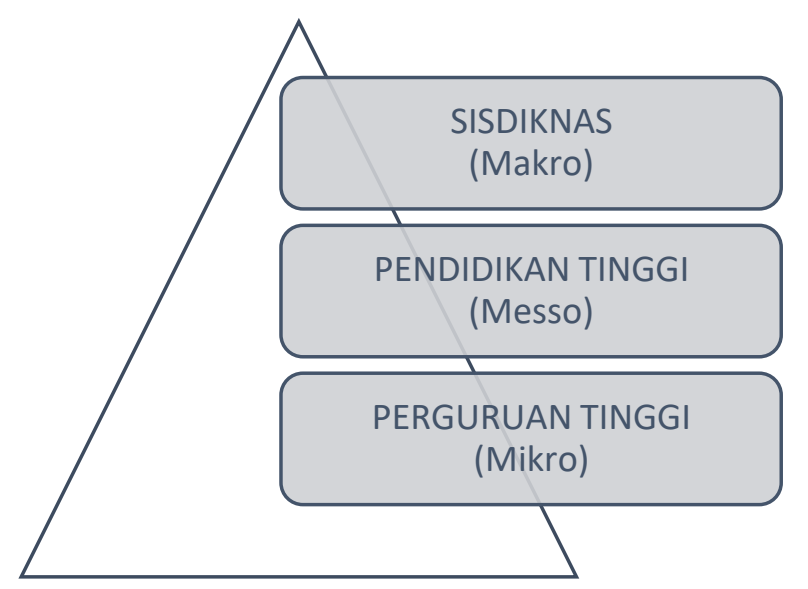

Gambar 1 Hirarki Perguruan Tinggi,

Pendidikan Tinggi, dan Sistem

Pendidikan Nasinal

Pendidikan tinggi merupakan lembaga formal jenjang terahir yang memberikan kontribusi peningkatan kompetensi sumber daya manusia sehingga memiliki kualifikasi dan keahlian tertentu, dengan menyediakan media pembelajaran dengan manajemen yang efektif dan efisien. Empat tantangan perguruan tinggi dalam era globalisasi yakni perdagangan, pergerakan modal, pergerakan orang, dan penyebaran ilmu pengetahuan dan teknologi (Suharsaputra, 2015). Empat aspek tersebut menjadi hal yang harus di tingkatkan dalam menjawab era perubahan dan pertumbuhan zaman.

Sekolah tinggi adalah salah satu jenis perguruan tinggi yang meneyelenggarakan pendidikan vokasi dalam suatu rumpun ilmu pengetahuan dan/atau teknologi tertentu untuk menciptakan suatu profesi. STIE IBMT SURABAYA merupakan perguruan tinggi yang berstatus sekolah tinggi, dengan disipliner ilmu manajemen diselenggarakan dalam jenjang pendidikan tinggi. Mutu pendidikan identik dengan hasil keluaran/output yang di proses secara maksimal oleh lembaga pendidikan (Zahroh, 2014). Output sebagai 
representatif lembaga pendidikan di masyarakat (Muhson, Wahyuni, \& Mulyani, 2012) dan proses terbentuknya sebuah outcome (Asmawi, 2005). Penguatan Manajemen Pendidikan dan Manajemen Mutu dalam perguruan tinggi harus di definisikan secara kemprehensif dan holistik (Fathoni, 2015).

Penelitian ini merupakan langkah awal sebagai upaya dalam memperhatikan proses penyelenggaraan pendidikan tinggi yang bermutu, sehingga penelitian ini memiliki tujuan untuk menganalisa penguatan menejemen pendidikan di perguruan tinggi, dan mengidentifikasi masalah mutu perguruan tinggi, serta mengukur kekuatan dan kelemahan, beserta peluang dan ancaman perguruan tinggi dalam menyelenggarakan pendidikan tinggi.

\section{METODE}

\section{Rancangan Penelitian}

Penelitian yang berjudul Penguatan Manajemen Pendidikan Dalam Mutu Pendidikan Tinggi Studi ini dilakukan dengan pendekatan kualitatif yang bertujuan untuk memahami situasi-situasi tempat penelitian dari partisipan atau informan. Partisipan atau informan pada penelitian ini merupakan orang yang diwawancara dan diobservasi yang diminta memberikan data, pendapat dan pemikiran. Penelitian kualitatif menggunakan desain penelitian studi kasus dalam arti penelitian difokuskan pada satu fenomena saja yang dipilih dan ingin dipahami secara mendalam, dengan mengabaikan fenomena-fenomena lainnya (Sukmadinata, 2010).

Rancangan penelitian pada dasarnya adalah merencanakan sesuatu kegiatan sebelum dilaksanakan penelitian, dapat juga diartikan sebagai usaha merencanakan dan menentukan segala kemungkinan dan perlengkapan yang diperlukan dalam suatu penelitian kualitatif, (Moleong, 2006). Penelitian ini menggunakan rancangan studi kasus, yang menggambarkan kasus sebagai objek penelitian dalam kondisi seadanya, rinci dan mendalam. Penguatan Manajemen Pendidikan dalam perguruan tinggi harus di definisikan secara kemprehensif dan holistik. Penelitian ini sebagai upaya yang dilakukan untuk memberikan penjelasan tentang peran manajemen pendidikan dalam mutu perguruan tinggi, yang akan dijelaskan dalam desain penelitian sebagai berikut:

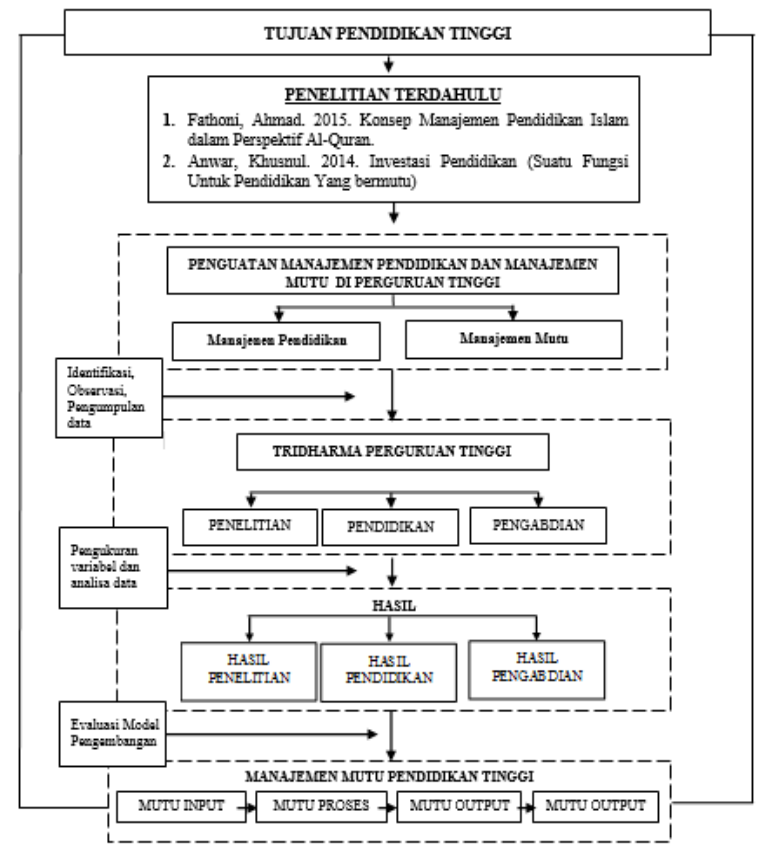

Gambar 2 Rancangan Penelitian

\section{Tahapan Kegiatan Penelitian}

Tahapan kegiatan penelitian ini merujuk kepada Johnson dan Cristensenv (Ulfatin, 2013) menjelaskan ada delapan tahapan yang sering dilalui peneliti dalam penelitian kualitatif dengan metode studi kasus, yang digambarkan dalam bentuk urutan kegiatan sebagai berikut:

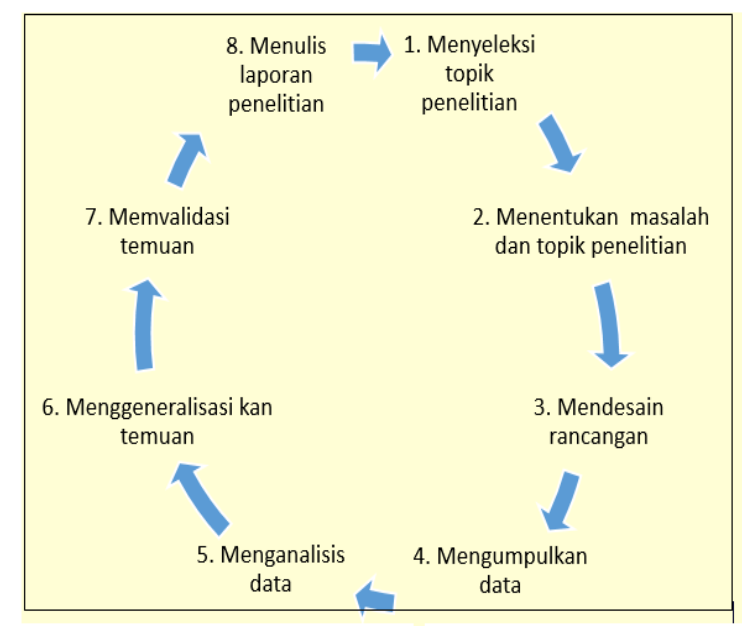

Gambar 3 Tahapan Penelitian Studi kasus

Tahapan penelitian studi kasus ini dapat dijelaskan bahwa (1) Menyeleksi topik penelitian, dan memilih topik dengan topik Mutu pendidikan Tinggi. 
Menentukan masalah dan topik penelitian, dengan mengidentifikasi masalahmasalah mengenai penguatan manajemen pendidikan dalam mutu di perguruan tinggi. (3) Mendesain rancangan, dengan menggunakan pendekatan kualitataif deskriptif dan metode studi kasus, (4) Mengumpulan data, bahwa dalam penelitian ini pengumpulan data menggunakan wawancara, observasi, dan dokumentasi. (5) Menganalisis data, dalam penelitian ini analisis data yang di gunakan adalah reduksi data, penyajian data, dan kesimpulan. (6) Menggeneralisasikan temuan, yaitu berupa kesimpulan dari hasil penelitian. (7) melakukan validasi data, yaitu dalam penelitian ini dengan mengecekan keabsahan data. (8) Menulis laporan penelitian. dst.tahapan penelitian beserta hasil kegiatan dijelaskan pada tabel berikut:

Tabel 1 Tahapan Kegiatan Penelitian

\begin{tabular}{|c|c|c|}
\hline No & $\begin{array}{l}\text { Tahapan } \\
\text { Kegiatan }\end{array}$ & Hasil Kegiatan \\
\hline 1 & $\begin{array}{l}\text { Studi } \\
\text { Pendahuluan }\end{array}$ & $\begin{array}{l}\text { - Kajian Empiris, } \\
\text { - Kajian Teoritis } \\
\text { dan } \\
\text { - Kajian Yuridis }\end{array}$ \\
\hline 2 & $\begin{array}{l}\text { Identifikasi } \\
\text { Masalah }\end{array}$ & $\begin{array}{l}\text { - Manajemen } \\
\text { Pendidikan dalam } \\
\text { Mutu Pendidikan } \\
\text { Tinggi } \\
\end{array}$ \\
\hline 3 & $\begin{array}{l}\text { Rancangan } \\
\text { Penelitian }\end{array}$ & $\begin{array}{l}\text { - Pendekatan } \\
\text { Kualitatif dengan } \\
\text { Metode } \\
\text { Studikasus }\end{array}$ \\
\hline 4 & $\begin{array}{l}\text { Pengumpulan } \\
\text { Data }\end{array}$ & $\begin{array}{l}\text { - Observasi, } \\
\text { - Dokumentasi, dan } \\
\text { - Wawancara }\end{array}$ \\
\hline 5 & $\begin{array}{l}\text { Analisis } \\
\text { Pengolahan } \\
\text { Data }\end{array}$ & $\begin{array}{l}\text { - Reduksi Data, } \\
\text { - Penyajian Data, } \\
\text { dan } \\
\text { - Kesimpulan }\end{array}$ \\
\hline 6 & $\begin{array}{l}\text { Penyusunan } \\
\text { Model }\end{array}$ & $\begin{array}{l}\text { - Temuan } \\
\text { - Hasil Penelitian }\end{array}$ \\
\hline 7 & $\begin{array}{l}\text { Validasi dan } \\
\text { Keabsahan } \\
\text { Data }\end{array}$ & $\begin{array}{l}\text { - Kredibilitas } \\
\text { (Perpanjangan } \\
\text { Pengamatan, } \\
\text { Triangulasi, dan } \\
\text { Member Check) } \\
\text { - Konfirmadibilitas }\end{array}$ \\
\hline
\end{tabular}

\begin{tabular}{lll}
\hline No & $\begin{array}{c}\text { Tahapan } \\
\text { Kegiatan }\end{array}$ & Hasil Kegiatan \\
\hline 8 & Laporan & • Dokumen \\
& Penelitian & Penelitian \\
& & - Publikasi IImiah \\
& & - Forum Ilmiah \\
\hline
\end{tabular}

\section{Teknik Pengumpulan Data}

Ada 3 teknik yang digunakan peneliti dalam pengumpulan data penelitian, yaitu: (1) wawancara, (2) observasi, dan (3) studi dokumentasi.

\section{Wawancara}

Dalam penelitian ini, pengumpulan data menggunakan wawancara dilakukan untuk mencari data konsep, pengalaman, dan pemikiran informan tentang apa yang terjadi dalam lokasi penelitian. Wawancara adalah suatu percakapan yang dilakukan oleh 2 (dua) pihak yaitu pewawancara (interviewer) dan yang diwawancarai (interviewe) yang memberikan jawaban atas pertanyaan itu (Moleong, 2006).

2. Observasi

Menurut Sutrisno Hadi (Sugiyono, 2010) mengemukakan bahwa "observasi merupakan suatu proses yang kompleks, suatu proses yang tersusun dari berbagai proses biologis dan psikologis. Dua diantara yang terpenting adalah pengamatan dan ingatan". Teknik pengumpulan data melalui observasi digunakan ketika berkenaan dengan penggalian data awal yang dibutuhkan dalam penelitian, seperti contohnya: perilaku manusia, proses kerja, gejalagejala alam dan lain sebagainya. Dalam penelitian ini menggunakan teknik observasi non-partisipan yakni peneliti tidak terlibat secara langsung dalam kegiatan sehari-hari dan hanya sebagai pengamat independen.

3. Dokumentasi

Penelitian ini dilengkapi dengan teknik pengambilan data dengan dokumentasi. Metode dokumentasi yaitu mencari data mengenai variabel-variabel yang berupa catatan, transkip, buku, surat kabar, majalah, prasasti, notulen rapat, lengger, agenda dan sebagainya (Arikunto, 2010). Dokumentasi yang akan disertakan oleh peneliti dalam penelitian seperti ringkasan profil, anggaran dasar dan anggaran 
rumah tangga koperasi wanita, data simpanan pokok dan simpanan wajib, beserta data lain sebagainya yang berkaitan dengan studi penelitian.

\section{Analisis Data}

Menurut Miles dan Huberman (Sugiyono, 2010) bahwa aktifitas dalam analisis data kualitatif dilakukan secara interktif dan berlangsung secara terus menerus sampai tuntas, sehingga datanya sudah jenuh. Aktifitas dalam analisis data, yaitu data reduction, data display, dan conclusion verification. Penjelasan aktifitas analisis data sebagai berikut:

1. Reduksi Data (Data Reduction)

Data hasil pengumpulan data melalui studi wawancara, observasi, dan dokumentasi yang beragam perlu dilakukan reduksi data. Reduksi data dapat diartikan sebagai proses pemilihan, merangkum, dan memfokuskan, serta penyederhanaan, hal yang lebih penting dan pokok dalam pengumpulan data.

Dalam reduksi data, pengkodean dilakukan untuk mengelompokkan data hasil penelitian yang diperoleh melalui proses wawancara, observasi dan dokumentasi. Reduksi data peneliti menggunakan mengkodean data untuk memperjelas dalam membaca pengumpulan data dengan hasil penelitian.

2. Penyajian Data / Data Display

Penyajian data dalam penelitian kualitatif berupa teks yang bersifat naratif, bagan, hubungan antar kategori, jaringan kegiatan kerja dan tabel juga dapat digunakan dalam menyajikan data agar mudah dipahami. Hasil yang didapatkan selama pengumpulan data tentang fokus penelitian, disajikan secara naratif dan digambarkan dalam bentuk bagan dan tabel untuk mempermudah pemahaman.

\section{Kesimpulan (Conclusion Drawing / Verification)}

Verifikasi data atau kesimpulan data dihasilkan dari reduksi data. Verifikasi data dilakukan dengan cara membandingkan, membuat pola-pola, mengelompokkan dan menelaah hal yang penting dalam reduksi data.

\section{Uji Keabsahan Data}

Keabsahan data dilakukan untuk menguji keberanan prespektif peneliti yang dilakukan melalui 4 macam kiteria seperti yang dikemukakan Licoln dan Guba (Riyanto, 2007), yaitu (1) kredibilitas, (2) transferabilitas, (3) dependabilitas, dan (4) konfirmabilitas. Berikut adalah penjelasan dari uraian di atas adalah:

\section{Kredibilitas}

Kredibilitas yaitu mengukur tingkat kebenaran atau keabsahan suatu penelitian dengan maksud agar peneliti dapat diterima pihak yang diteliti. Dengan kriteria ini data dan informasi dapat dikumpulkan harus mengandung nilai kebenaran, yang berarti bahwa hasil penelitian kualitatif harus dapat dipercaya oleh para pembaca yang kritis dan dapat diterima oleh orang-orang informan yang memberikan informasi berlangsung (Riyanto, 2007).

2. Transferabilitas

Transferabilitas yaitu penelitian yang dilakukan dalam konteks tertentu dapat diaplikasikan atau ditransfer pada konteks (setting) lain dimana hasil penelitian akan diterapkan (Moleong, 2006). Dalam penelitian ini menggunakan uraian rinci. Teknik ini digunakan untuk mengetahui hasil penelitian harus dicermati, dimana penelitian dilakukan dan membandingkan sendiri hasil penelitian dapat ditransfer pada situasi lain. Dengan teknik ini peneliti melaporkan hasil penelitian secara jelas dan rinci yang dapat menggambarkan kondisi tempat penelitian yang diteliti dan dilaksanakan sesuai dengan fokus penelitian.

\section{Dependabilitas}

Dependabilitas yaitu cara untuk mengecek kualitas proses dalam penelitian, maka peneliti dalam teknik dependabilitas mengecek hasil penelitian secara keseluruhan, mulai dari studi pendahuluan, proses aktifitas penelitian di lapangan, menentukan sumber data, melakukan analisis data, melakukan uji keabsahan data dan kesimpulan data.

4. Konfirmabilitas

Konfirmabilitas merupakan uji objektifitas penelitian. Semua hasil penelitian yang dilakukan mulai dari uji kredibilitas, transfermabilitas, dependabilitas dan konfirmabilitas ini, oleh peneliti dan informan sebagai auditor penelitian telah disepakati bersama hasil 
penelitian ini. Konfirmabilitas penelitian ini dilakukan melalui pengumpulan data, informasi dan hasil penelitian.

\section{HASIL DAN PEMBAHASAN}

Hasil penelitian disajikan dalam sistem pengkodean analisis data, meliputi (1) Kode kasus latar penelitian, (2) Teknik pengumpulan data, (3) Sumber data yang dijadikan informan penelitian, (4) Fokus penelitian, yang dijelaskan pada tabel berikut:

Tabel 2 Kode Aspek Penelitian

\begin{tabular}{|c|c|c|}
\hline No & Aspek & Kode \\
\hline 1 & $\begin{array}{l}\text { Studi Kasus } \\
\text { Manajemen Pendidikan dalam } \\
\text { mutu pendidikan tinggi }\end{array}$ & I \\
\hline 2 & $\begin{array}{l}\text { Teknik Pengumpulan Data } \\
\text { a. Wawancara } \\
\text { b. Observasi } \\
\text { c. Dokumentasi }\end{array}$ & $\begin{array}{l}W \\
O \\
D\end{array}$ \\
\hline 3 & $\begin{array}{l}\text { Sumber Data } \\
\text { a. Rektor } \\
\text { b. Wakil Ketua I } \\
\text { c. Wakil Ketua II } \\
\text { d. Wakil Ketua III } \\
\text { e. Kepala Penjamin Mutu } \\
\text { Pendidikan Tinggi } \\
\text { f. Kepala LPPM } \\
\text { g. Dosen dan Staf }\end{array}$ & $\begin{array}{c}\text { RK } \\
\text { WK } 1 \\
\text { WK } 2 \\
\text { WK } 3 \\
\text { KLP3 } \\
\text { KLP2 } \\
\text { DS }\end{array}$ \\
\hline 4 & $\begin{array}{l}\text { Fokus Penelitian } \\
\text { a. Implementasi Manajemen } \\
\text { Pendidikan Tinggi } \\
\text { b. Implementasi Manajemen } \\
\text { Mutu Pendidikan Tinggi } \\
\text { c. Usaha-usaha yang } \\
\text { dilakukan dalam } \\
\text { penguatan manajemen } \\
\text { penidikan dalam mutu } \\
\text { perguruan tinggi. }\end{array}$ & $\begin{array}{l}\text { IMPT } \\
\text { IMMPT }\end{array}$ \\
\hline
\end{tabular}

Penguatan Manajemen Pendidikan dalam Mutu Perguruan Tinggi di STIE IBMT Surabaya, telah dilakukan pengumpulan data, analisa data, dan uji keabsahan data, sebagai berikut:

\section{Implementasi Penguatan Manajemen}

\section{Pendidikan Tinggi}

1. Penguatan manajemen pendidikan tinggi dalam di STIE IBMT Surabaya dilakukan dalam bentuk nilai-nilai, sebagai berikut:

$$
\begin{aligned}
& \text { I - ntergrity } \\
& \text { B - reakthrough } \\
& \text { M - agnifiencence } \\
& \text { T - ogether }
\end{aligned}
$$

2. STIE IBMT Surabaya sebagai Perguruan Tinggi dengan disipliner ilmu manajemen dan bisnis menyelenggarakan pendidikan tinggi memiliki prinsip sebagai berikut:

- Kondusif: Memberikan fasilitas yang mendukung pengembangan potensi mahasiswa;

- Adaptif: Memberikan metode-metode perkuliahan yang disesuaikan dengan tuntutan dan perkembangan zaman;

- Fleksibel: Membuka peluang terhadap masukan kritikan, dan ancaman yang ada menjadi dasar utama merubah kelemahan menjadi kekuatan;

- Solutif : Melakukan inovasi-inovasi yang mendukung untuk terwujudnya tujuan pendidikan nasional.

\section{Implementasi Manajemen Mutu \\ Pendidikan Tinggi}

1. Manajemen mutu dilakukan dalam perguruan tinggi guna menjamin relevansi antara tujuan pendidikan nasional, tujuan pendidikan tinggi, dan tujuan perguruan tinggi (Sumardjoko, 2010). Relevansi tersebut direalisasikan melalui tiga hal dasar yang harus dipenuhi oleh organisasi pendidikan yakni materi (sumber daya fisik, sarana dan prasarana), Energi (Komitmen, motivasi, kompetensi, belajar, perbaikan secara berkelanjutan, struktur organisasi, dan infrastruktur sistem organisasi), dan Informasi (Pengetahuan, visi-misi, tujuan, saasaran, inovasi, dan ilmu pengetahuan teknologi) (Rusmini,

\begin{tabular}{|c|c|c|c|c|}
\hline Kombinasi & A & B & C & Implikasi \\
\hline 1 & $\sqrt{ }$ & $\sqrt{ }$ & - & $\begin{array}{l}\text { - Organisasi adoptif- } \\
\text { adaptif } \\
\text { - Kinerja rutin adoptif- } \\
\text { adaptif } \\
\text { - Alokasi sumber daya } \\
\text { efektif dan efisien } \\
\text { - Daya saing rendah }\end{array}$ \\
\hline 2 & $\sqrt{ }$ & - & $\sqrt{ }$ & $\begin{array}{l}\text { - Organisasi adoptif- } \\
\text { adaptif } \\
\text { - Kinerja rutin adoptif- } \\
\text { adaptif } \\
\text { - Alokasi sumber daya } \\
\text { efektif dan efisien }\end{array}$ \\
\hline
\end{tabular}
2014).

Tabel 3 Relevansi Sisdiknas dan Perguruan Tinggi 


\begin{tabular}{ll|l}
\hline \multicolumn{1}{c}{} & $\bullet$ Daya saing sedang \\
\hline 3 & $\sqrt{ } \sqrt{ } \sqrt{ }$ & $\bullet$ Organisasi inovatif, \\
& $\bullet$ kinerja inovatif \\
& produktif, \\
& $\bullet$ alokasi sumber daya \\
& efektif dan efisien, \\
& memiliki daya saing \\
& tinggi \\
\hline
\end{tabular}

Keterangan:

A: Materi

B: Energi

C: Informasi

2. Implementasi manajemen mutu di kristalisasikan dalam visi perguruan tinggi yang disusun oleh jajaran pimpinan dan lembaga penjamin mutu perguruan tinggi (LP3M) (Gumiandari, 2013) dengan mengandung makna, sebagai berikut:

- Profesional: Memiliki keahlian dalam suatu bidang ilmu.

- Spesialisasi,

- Kompetensi,

- Kualifikasi,

- Transformasional : Perubahan terhadap kondisi tertentu menjadi kondisi yang lebih baik, dan Mengembalikan suatu keadaan untuk kembali kepada prinsip dan pedomannya thrureformation).

- Leadership

- Manajerial

- Policy making

- Internasional : Survive dan eksis baik dalam lingkup nasional maupun internasional.

- Mutu / Unggul,

- Kompetitif,

- Dinamis

- Aplikatif.

3. Manajemen mutu perguruan tinggi yang di didukung oleh peran LPPM (Lembaga Penelitian dan Pengabdian Kepada Masyarakat) yang hadir sebagai lembaga dengan tugas pengembangan unggulan spesifik; meningkatkan kapasitas penelitian dan pengabdian kepada masyarakat; yang direlevansikan dengan kebutuhan masyarakat Indonesia, dan memberikan perlindungan kekayaan intelektual secara nasional dan internasional (Syukron, 2017).

\section{Usaha-usaha yang dilakukan dalam penguatan manajemen penidikan dalam mutu perguruan tinggi.}

1. Merumuskan Rencana Strategis perguruan tinggi, yang mencakup:

a. Provide Meaningful, Experiential and Life-style Learning

Proses perkuliahan yang di desain untuk mempersiapkan calon pemimpin yang memiliki kapabilitas bisnis dan manajerial prima dengan berwawasan global, dengan menekankan pada penalaran konseptual; semangat belajar berkelanjutan, skills dalam menyelesaikan masalah; serta sikap professional yang menjunjung tinggi etika.

b. Appreciate Integrity

Mengembangkan proses dan membangun suasana akademik yang menghargai perbedaan pendapat dan keberagaman yang berlandaskan semangat integritas tinggi.

c. Train Capable Learning Leaders Mengembangkan kompetensi dan komitmen pendidik dengan cara menerapkan tridharma perguruan tinggi.

d. Contribute To The Welfare Of Local And Global Community Etchically Menjadi mitra pengembangan manajemen melalui kerjasama dengan lembaga kajian ilmiah swasta maupun negeri dengan cara membangun relasi dan jaringan komunikasi, informasi ilmiah dokumentasi/publikasi data serta perpustakaan yang lengkap dan aktual.

2. Merumuskan standarisasi tridharma perguruan tinggi, yang dijelaskan pada gambar berikut 


\begin{tabular}{|c|c|c|}
\hline $\begin{array}{l}\text { Standar Nasional } \\
\text { Pendidikan }\end{array}$ & $\begin{array}{l}\text { Standar Nasional } \\
\text { Penelitian }\end{array}$ & $\begin{array}{l}\text { Standar Nasional } \\
\text { PKM }\end{array}$ \\
\hline \multirow{2}{*}{$\begin{array}{l}\text { Standar Kompetensi } \\
\text { Lulusan }\end{array}$} & Standar Has' Penelitian & Standar Hasil PKM \\
\hline & Standar Isi Penelitian & Standar Isi PKM \\
\hline Standar Isi Pembelajaran & Standar Proses Penelitian & Standar Proses PKM \\
\hline \multirow{2}{*}{$\begin{array}{l}\text { Standar Proses } \\
\text { Pembelajaran }\end{array}$} & & \\
\hline & Standar Penilaian & Standar Penilaian PKM \\
\hline \multirow{2}{*}{$\begin{array}{l}\text { Standar Penilaian } \\
\text { Pembelajaran }\end{array}$} & Penellitan & Standar Pelaksana PKM \\
\hline & Standar Peneliti & Standar Sarncas PKM \\
\hline \multirow{2}{*}{$\begin{array}{l}\text { Standar Dosen dan Tenagaa } \\
\text { Kependidikan }\end{array}$} & \multirow{2}{*}{ Standar Sarpras Penelitian } & 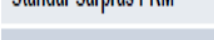 \\
\hline & & Standar Pengelolaan PKM \\
\hline $\begin{array}{l}\text { Standar Sarana dan } \\
\text { Prasarana Pbelajaran }\end{array}$ & $\begin{array}{l}\text { Standar Pengelolaan } \\
\text { Penelitian }\end{array}$ & $\begin{array}{l}\text { Standar Pendanaan \& } \\
\text { Pembiayaan PKM }\end{array}$ \\
\hline $\begin{array}{l}\text { Standar Pengelolaan } \\
\text { Pembelajaran }\end{array}$ & $\begin{array}{l}\text { Standar Pendanaan \& } \\
\text { Pembiayaan Penelitian }\end{array}$ & \\
\hline $\begin{array}{l}\text { Standar Pembiayaan } \\
\text { Pembelajaran }\end{array}$ & & \\
\hline
\end{tabular}

Gambar 4 Standarisasi Tridharma Perguruan Tinggi

3. Laporan kinerja perguruan tinggi berbasis luaran adalah rekapitulasi hasil penelitian dan pengabdian masyarakat yang telah dilakukan sesuai dengan kategori yang telah ditetapkan oleh STIE IBMT Surabaya. Berikut rekapitulasi pada Tahun 2016 2019 (3 tahun Terahir) dijelaskan pada gambar berikut:

\begin{tabular}{|c|c|c|c|c|c|c|}
\hline \multirow{2}{*}{ No } & \multirow{2}{*}{\multicolumn{2}{|c|}{ LUARAN PENEUTIAN }} & \multicolumn{4}{|c|}{ TAHUN } \\
\hline & & & 2019 & 2018 & 2017 & 2016 \\
\hline & \multirow{3}{*}{ PUBUKASI ILMIAH } & Internasional/Reputasi/Scopus & - & 1 & - & - \\
\hline 1 & & Nasional/Terakreditasi & - & 1 & 3 & - \\
\hline & & Internal & - & 8 & - & 2 \\
\hline \multirow{3}{*}{2} & \multirow{3}{*}{ FORUMILMIAH } & Seminar & - & - & - & - \\
\hline & & Prosiding & - & 1 & 1 & 1 \\
\hline & & Diseminasi & - & - & - & - \\
\hline 3 & \multicolumn{2}{|c|}{ HKL, PATEN, HAK CIPTA, DLL } & - & & - & - \\
\hline 4 & \multicolumn{2}{|c|}{ MODEL/PROTOTYPE/DESAIN/KARYASEN//REKAYASA SOSIAL } & - & & - & - \\
\hline 5 & \multicolumn{2}{|c|}{ TEKNOLOGI TEPAT GUNA } & - & & - & - \\
\hline 6 & \multicolumn{2}{|l|}{ BAHAN AJAR } & - & & 1 & - \\
\hline 7 & \multicolumn{2}{|c|}{ LAPORAN PENELITIAN YANG TIDAK DIPUBUIKASIKAN } & - & & & - \\
\hline & \multicolumn{2}{|c|}{ ЈUМLAH } & - & 12 & 4 & 3 \\
\hline
\end{tabular}

Gambar 5 Luaran Penelitian Tahun 2015 2019

Laporan kinerja perguruan tinggi yang dilihat dari hasil rekapitulasi kegiatan penelitian dan pengabdian kepada masyarakat menunjukan peningkatan yang drastis dalam tiga tahun terakhir (2016-2017-2018).

\section{Matriks hasil Penelitian}

Tabel 4 Hasil Penelitian

\begin{tabular}{|c|c|c|c|}
\hline$\overline{\text { No }}$ & $\begin{array}{c}\text { Fokus } \\
\text { penelitian }\end{array}$ & Temuan Penelitian & Sumber \\
\hline 1 & IMPT & $\begin{array}{l}\text { 1. Manajemen } \\
\text { pendidikan tinggi } \\
\text { dalam di STIE IBMT } \\
\text { Surabaya di } \\
\text { implementasikan } \\
\text { melalui nilai-nilai : } \\
\text { I-ntergrity } \\
\text { B-reakthrough } \\
\text { M-agnifiencence } \\
\text { T-ogether }\end{array}$ & RK \\
\hline
\end{tabular}

2. Penyelenggaraan Perguruan Tinggi dengan disipliner ilmu manajemen dan bisnis menyelenggarakan pendidikan tinggi memiliki prinsip prinsip sebagai berikut: Kondusif

Adaptif

Fleksibel Solutif

2 IMMPT 1. Manajemen mutu dilakukan dalam perguruan tinggi guna menjamin relevansi antara tujuan pendidikan nasional, tujuan pendidikan tinggi, dan tujuan perguruan tinggi.

KLP3

2. Manajemen mutu dikristalisaikan dan di amanatkan dalam sebuah visi perguruan tinggi yang mencakup unsur sebagai berikut:

Profesional Transformasional Internasional

3. Menjalankan tridharma perguruan tinggi dalam sesuai dengan rumpun ilmu ekonomi dan manajemen yang membidangi sosial humaniora dan teknologi informasi komunikas 


\begin{tabular}{|c|c|c|c|}
\hline$\overline{\text { No }}$ & $\begin{array}{c}\text { Fokus } \\
\text { penelitian }\end{array}$ & Temuan Penelitian & Sumber \\
\hline & UUP & $\begin{array}{l}\text { 1. Merumuskan } \\
\text { Rencana Strategis } \\
\text { perguruan tinggi }\end{array}$ & RK \\
\hline & & $\begin{array}{l}\text { 2. Merumuskan } \\
\text { Standarisasi } \\
\text { Perguruan Tinggi } \\
\text { 3. Laporan Kinerja } \\
\text { Perquruan tingqi }\end{array}$ & KLP2 \\
\hline
\end{tabular}

\section{KESIMPULAN}

Perguruan tinggi sebagai penyelenggara pendidikan di jenjang tertinggi diperlukannya sebuah rancangan dalam bentuk rencana strategis yang disesuaikan dengan kharakteristik dan kebutuhan yang diformulasikan dalam bentu visi dan misi perguruan tinggi. Implementasi pendidikan tinggi melalui perguruan tinggi harus kondusif, adaptif, dan fleksibel serta memberikan antisipasi dan solusi terhadap tuntutan perubahan dan perkembangan di masyarakat. Penguatan manajemen pendidikan suatu aspek tentang bagaimana mengelola dan memberdayakan sumber daya untuk mencapai tujuan pendidikan yang telah ditetapkan secara produktif dan kondusif kian memiliki peranan yang penting dalam menentukan mutu perguruan tinggi yang akan berdampak kepada tercapainya tujuan pendidikan nasional. Relevansi tersebut direalisasikan melalui tiga hal dasar yang harus dipenuhi oleh organisasi pendidikan yakni materi, energi, dan informasi.

\section{SARAN}

Berdasarkan kesimpulan diatas, terdapat beberapa saran yang ditujukan kepada:

1. Ketua STIE IBMT Surabaya.

Diharapkan dengan hasil penelitian ini dapat meningkatkan dukungan moral, spritual, dan finansial kepada seluruh sivitas perguruan tinggi dalam mewujudkan tridharma perguruan tinggi melalui penguatan manajemen pendidikan tinggi.

2. Pimpinan Penjamin Mutu STIE IBMT Surabaya.

Dikarenakan tidak ada temuan yang bersifat negatif yang berkaitan manajemen mutu perguruan tinggi, diharapkan lembaga penjamin mutu perguruan tinggi mampu untuk mempertahankan dan meningkatkan kinerja kinerja perguruan tinggi.

3. Peneliti lain

Di harapkan penulisan ini dapat dijadikan referensi terkait dengan penelitian menajemen pendidikan dan manajemen mutu pendidikan tinggi, peneliti lain dapat melakukan penelitian pengembangan atau lanjutan yang relevan dengan pendekatan dan setting yang berbeda.

\section{DAFTAR RUJUKAN}

Anwar, K. (2014). Investasi Pendidikan (Suatu Fungsi Untuk Pendidikan Yang Bermutu). Al-Fikrah, 1-10.

Arikunto, S. (2010). Prosedur Penelitian Suatu Pendekatan Praktik. Jakarta: Rineka Cipta.

Asmawi, M. R. (2005). Strategi Meningkatkan Lulusan Bermutu di Perguruan Tinggi. Makara Seri Sosial Humaniora, 9(2), 66-71.

Basri, H., \& Rusdiana. (2015). Manajemen Pendidikan dan Pelatihan. Bandung: Pustaka Setia.

Fathoni, A. (2015). Konsep Manajemen Pendidikan Islam dalam Perspektif Al-Quran. Al-Idarah Jurnal Manajemen Pendidikan, 5(2), 100120.

Gumiandari, S. (2013). Komitmen Pimpinan Dalam Pelaksanaan Penjaminan Mutu Perguruan Tinggi (Studi Kasus IAIN Syekh Nurjati Cirebon). Holistik, 14(02), 27-56.

Moleong, L. J. (2006). Metodologi Penelitian Kualitatif Edisi Revisi. Bandung: Remaja Rosdakarya.

Muhson, A., Wahyuni, D., \& Mulyani, E. (2012). Analisis Relevansi Lulusan Perguruan Tinggi Dengan Dunia Kerja. Jurnal Economia, 8(1), 42-52.

Nuraeni, Y. (2010). Perancangan Sistem Informasi Penjaminan Mutu Perguruan Tinggi Bidang Sumber 
Daya Manusia. Journal of Information

System, 6(1), 32-43.

Riyanto, Y. (2007). Metode Penelitian

Pendidikan Kualitatif dan Kuantitatif.

Surabaya: Unesa University Press.

Rusmini. (2014). Konsep Manajemen

Pendidikan Dalam Konteks Kinerja

Organisasi Unggul. Al-Fikrah, 139149.

Sugiyono. (2010). Metode Penelitian

Pendidikan Pendekatan Kuantitatif, Kualitatif dan R\&D. Bandung:

Alfabeta.

Suharsaputra, U. (2015). Manajemen

Pendidikan Perguruan Tinggi.

Bandung: Refika Aditama.

Sukmadinata, N. S. (2010). Metode

Penelitian Pendidikan. Bandung:

Remaja Rosdakarya.

Sumardjoko, B. (2010). Faktor-Faktor

Determinan Peran Dosen Dalam

Penjaminan Mutu Perguruan Tinggi.

Cakrawala Pendidikan, 29(3), 294-

310.

Syukron, B. (2017). Implementasi

Manajemen Mutu Terpadu: Studi

Transformasi Pada Perguruan Tinggi.

Jurnal Pendidikan Ekonomi Dan

Bisnis, 5(1), 51-62.

Ulfatin, N. (2013). Metode Penelitian

Kualitatif. Malang: Bayumedia

Publishing.

Zahroh, A. (2014). Total Quality

Management Teori dan Praktik

Mnajemen Untuk Mendongkrak Mutu

Pendidikan. Yogyakarta: Ar-Ruzz

Media. 